\title{
Formulation of Natural Curing in the Manufacturing of Dendeng Sapi - Indonesian Dried Beef from Local Beef Cattle
}

\author{
Saputro E \\ National Animal Husbandry Training Center, Ministry of Agriculture, Indonesia \\ Jl. Songgoriti 24, Batu 65301, East Java, Indonesia \\ ekosaputrobbppbatu@gmail.com
}

\begin{abstract}
This study was conducted to investigate the formulation of natural curing by various levels of fresh celery leaves (FCL) and incubation temperature. The incubation temperature was room temperature (RT) and temperature of $40.6^{\circ} \mathrm{C}(40.6)$ for 2 hours. These incubation temperatures for manufacturing dendeng sapi were designed to provide the similar curing characteristics of the control (conventional curing by addition of $50 \mathrm{ppm}$ of $\mathrm{NaNO}_{2}$ ). Four naturally cured dendeng sapi treatments were $\mathrm{A}_{1}=22 \mathrm{~g}$ FCL $/ \mathrm{kg}$ of beef, RT; $\mathrm{A}_{2}=36 \mathrm{~g}$ FCL $/ \mathrm{kg}$ of beef, RT; $\mathrm{A}_{3}=22 \mathrm{~g} \mathrm{FCL} / \mathrm{kg}$ of beef, $40.6^{\circ} \mathrm{C} ; \mathrm{A} 4=36 \mathrm{~g} \mathrm{FCL} / \mathrm{kg}$ of beef, $40.6^{\circ} \mathrm{C}$ and a treatment of conventionally cured dendeng sapi by addition of $50 \mathrm{ppm} \mathrm{NaNO}_{2}$ as a control $\left(\mathrm{A}_{0}\right)$. All sensory quality attributes (cured aroma, cured color, color uniformity, firmness, celery aroma and celery flavor among all treatments were significantly different $(\mathrm{P}<0.05)$ except cured flavor $(\mathrm{P}>0.05)$. The control $\left(\mathrm{A}_{0}\right)$ received the highest scores for cured aroma $(\mathrm{P}<0.05)$, cured flavor (not significant), cured color $(\mathrm{P}<0.05)$, color uniformity $(\mathrm{P}<0.05)$ and the most tender $(\mathrm{P}<0.05)$ than all natural curing treatments without the addition of $\mathrm{NaNO}_{2}\left(\mathrm{~A}_{1}-\mathrm{A}_{4}\right)$. Sensory analysis showed celery aroma and flavor scores which tend to approach undetectable as a result of the closure of (masking) by spices used. Treatments of $\mathrm{A}_{1}-\mathrm{A}_{4}$ showed similar to the control for the measurements of proximate, water activity, cook yield, color, cured pigment, total pigment, residual nitrite and cured flavor. They showed more effectively suppress the lipid oxidation compared to the control. These results indicated that natural curing treatment by $22 \mathrm{~g}$ of FCL and incubated at room temperature $\left(\mathrm{A}_{1}\right)$ is the best of natural curing formulation.
\end{abstract}

Key Words: Natural Curing, Fresh Celery Leaves, Sensory Quality, Chemical Quality, Dendeng Sapi

\section{INTRODUCTION}

Dendeng sapi is Indonesian preserved beef by chemically and physically preservation. Dendeng sapi is made with the addition of kitchen salt $(\mathrm{NaCl})$, saltpetre (sodium nitrate/nitrite), sugar and Indonesian typical spices as a seasoning on thin slices of meat or ground meat then dried using sunlight or using a drying oven. Dendeng sapi is included conventional curing meat products because of use of saltpeter (sodium nitrate/nitrite) in the composition of raw material. The negative effects of nitrite have invited concerns through food safety which can cause methaemoglobinemia and the formation of carcinogenic $\mathrm{N}$ nitrosamine have become the reason many researchers to find alternative healthier and safer natural curing.

Sebranek \& Bacus (2007) had described the process of meat curing called natural curing. This process uses natural ingredients that contain relatively high levels of nitrate naturally combined with a starter culture of bacteria that produce enzyme of nitrate reductase to reduce nitrate to nitrite. Some vegetables, such as celery, have been shown to have high level of natural nitrate (Walker 1990; Fujihara et al. 2001). Reduction of nitrate to nitrite by the starter culture is done through the incubation step at a temperature that meets the specific requirements of the growth of the microorganism used and carried over a certain period before the cooking/thermal processing step. Previous researches have 
recommended a minimum of 2 hours incubation for the generation of enough nitrite then to develop the characteristics of cured meat (Sindelar et al. 2007a; Sindelar et al. 2007b).

Previous researches by Sindelar et al. (2007a); Sindelar et al. (2007b); Sindelar et al. (2010); Terns et al. (2011a) and Terns et al. (2011b) used the natural curing agents in the form of vegetables or fruit juice powdered and Staphylococcus carnosus that produce nitrate reductase enzyme that is able to reduce nitrate to nitrite. The authors did study by trying to use only natural curing agent in the form of fresh celery leaves (FCL) that naturally contains high nitrate and enzyme of nitrate reductase without the addition of nitrate-reducing bacteria. Nitrate reduction relied on enzyme of nitrate reductase contained in the leaves of fresh celery and produced by the nitrate-reducing bacteria according to McDougall et al. (1975); Sebranek (1979); Sanz et al. (1997) and Pinotti et al. (2001) naturally found in fresh meat. This study aimed to investigate the formulation of various concentrations of fresh celery leaves and incubation temperatures that affect both the quality of some chemical and sensory characteristics of dendeng sapi during product manufacture and then during storage times of finished products that is similar to the control added with synthetic sodium nitrite.

\section{MATERIAL AND METHODS}

\section{Materials and experimental design}

Materials of dendeng sapi used included: ground of fresh bottom round from local bulls of ongole crossbreed (OC) about 3 years from Penggaron abattoir (slaughterhouse) Semarang City, sugar, spices and fresh celery leaves from Bandungan, Semarang Regency were used to produce dendeng sapi natural curing.

The study used the experimental design of split-plot on the basis of a randomized complete block design consisting 3 replicate groups of each. The main plot was curing treatments (A) consisting 4 natural curing treatments by various levels of FCL and incubation temperature for 2 hours (room temperature $=\mathrm{RT}$ and temperature of $40.6^{\circ} \mathrm{C}$ ). The levels of FCL were $\mathrm{A}_{1}=22 \mathrm{~g}$ FCL $/ \mathrm{kg}$ of beef, RT; $\mathrm{A}_{2}=36 \mathrm{~g}$ FCL $/ \mathrm{kg}$ of beef, RT; $\mathrm{A}_{3}$ $=22 \mathrm{~g} \mathrm{FCL} / \mathrm{kg}$ of beef, $40.6^{\circ} \mathrm{C} ; \mathrm{A}_{4}=36 \mathrm{~g} \mathrm{FCL} / \mathrm{kg}$ of beef, $\left.40.6^{\circ} \mathrm{C}\right)$ and a treatment of conventional curing by $50 \mathrm{ppm}$ sodium nitrite-added as a control $\left(\mathrm{A}_{0}\right)$. The subplot was 3 periods of storage or $0,14^{\text {th }}$ and $28^{\text {th }}$ observation days with the sample of their own. The replicate groups were the origin of bottom round 1,2 and 3.

Bottom round was trimmed in order to clean of external fat and ground, then was randomly placed in a container (each $1 \mathrm{~kg}$ for each treatment). Dendeng sapi formulation based Suryati et al. (2014) consisted of the following materials: $1 \mathrm{~kg}$ of ground bottom round, $16.5 \%$ brown sugar, $16.5 \%$ white sugar, $10 \%$ garlic, $8.5 \%$ galangal, $2.5 \%$ salt, $2.0 \%$ coriander, $0.3 \%$ white pepper, $0.3 \%$ tamarind, $0.3 \%$ lime and $0.3 \%$ ice/water (based on the weight of the beef). Treatment of $A_{0}$ was addition of $50 \mathrm{ppm}$ of sodium nitrite; treatment of $A_{1}$ and $A_{3}$ were added $22 \mathrm{~g}$ of fresh celery leaves; and treatment of $A_{2}$ and $A_{4}$ were added $36 \mathrm{~g}$ of FCL. The mixture of dendeng sapi $\mathrm{A}_{1}$ and $\mathrm{A}_{2}$ were incubated for 2 hours at room temperature. The mixture of dendeng sapi $\mathrm{A}_{3}$ and $\mathrm{A}_{4}$ were placed in an incubator and incubated for 2 hours at a temperature of $40.6^{\circ} \mathrm{C}$. The control (A0) was dried directly in the oven after flaked by a thin 0.1 to $0.2 \mathrm{~cm}$ without incubation step. All treatments were dried using a drying oven for 2 hours at $63^{\circ} \mathrm{C}$ and reversed such that the bottom side was at the top, and then the drying was continued at $63^{\circ} \mathrm{C}$ for 2 hours to reach a water activity $\leq 0.85$. After the drying was complete, dendeng sapi pieces of each treatment for each sample of $0,14^{\text {th }}$ and $28^{\text {th }}$ day were placed in a plastic barrier bag polypropylene (PP) and packaged 
vacuum. They were stored at room temperature in a tightly closed container and opaque until chemical and trained sensory quality analysis.

\section{Research parameters}

Cook yield of each treatment was expressed in percent and determined by dividing the dry weight by the total weight of raw materials and multiplying by 100 . Water activity $\left(a_{w}\right)$ was measured using a water activity meter from two different dendeng sapi slices from each treatment. The average was used for statistical analysis. Commission International d'Eclairage (CIE) $L^{*}$ (lightness), $a^{*}$ redness) and $b^{*}$ (yellowness) were determined using a digital colorimeter for Macintosh. Measurements of surface color dendeng sapi were taken after the products were removed from vacuum packaging. Measurements were taken at 6 randomly selected areas on the sample and the average was used in data analysis. Proximate composition measured include: crude fat (AOAC 1990a), moisture (AOAC $1990 \mathrm{~b}$ ) and crude protein (AOAC 1993). The $\mathrm{pH}$ of dendeng sapi samples were determined according to the methods of Sebranek et al. (2001). Measurement of each treatment was performed in duplicate and the average was used in data analysis. Lipid oxidation was measured by peroxide value test (AOAC 1997) on the $28^{\text {th }}$ day storage of dendeng sapi. Peroxide value was reported as mg equivalent $\mathrm{O}_{2} / \mathrm{kg}$ sample of dendeng sapi. Mononitrosylhemochrome pigment (cured meat pigment) and total pigment concentrations were measured using a method of Hornsey (1956), after extraction in $80 \%$ acetone and acidified acetone, respectively. Residual nitrite was determined before incubation (preincubate), after incubation (postincubate), after drying (day 0) and continuing throughout a 28-day storage times. Residual nitrite were determined by the AOAC method (AOAC 1990c). All residual nitrite assays were done in duplicate and all treatments within a replication were analyzed at the same time to minimize the variation in the analysis due to time. Sensory test carried out by the method according Sindelar et al. (2007a) by 14 trained panelists that was performed on the $14^{\text {th }}$ day after the manufacture of the product in order to mimic the approximate time period of initial product availability in a commercial distribution chain. Attributes of sensory quality were measured using a scale line (numerical value of 15 units) with graduation from 0 to 15 where 0 represented none (aroma and flavor), not uniform (color), low (color) and soft (firmness) and 15 represented intense (aroma and taste), uniform (color), high (color) and hard (firmness).

\section{Data analys is}

Statistical analysis was performed for all measurement datas using the SPSS procedures (version 17.0) using analysis of variance (ANOVA). The differences between treatments were tested further using the Tukey test. Especially for sensory datas were tested by non-parametric test (the Kruskal Wallis test) and the differences between treatments were tested further using the Mann Whitney test. Significance level was determined at $\mathrm{P}<0.05$.

\section{RESULTS AND DISCUSSION}

\section{Product processing attributes}

Various products processing parameters were measured and recorded during the manafacture of dendeng sapi are presented in Table 1. Preincubated $\mathrm{pH}$ ranged from 6.03 to 6.08 and no differences $(\mathrm{P}>0.05)$ were found between the treatments. Postincubate $\mathrm{pH}$ 
ranged from 6.12 to 6.27 and no differences $(\mathrm{P}>0.05)$ were found between the treatments. Postincubate $\mathrm{pH}$ for control $\left(\mathrm{A}_{0}\right)$ was not measured because there was no incubation step applied to the control.

Table 1. Means for product processing attributes and peroxide value

\begin{tabular}{|c|c|c|c|c|c|c|}
\hline \multirow{2}{*}{ Treatments } & \multicolumn{2}{|r|}{ Preincubate } & \multirow{2}{*}{$\begin{array}{c}\text { Postincubate } \\
\mathrm{pH}\end{array}$} & \multirow{2}{*}{$\mathrm{a}_{\mathrm{w}}$} & \multirow{2}{*}{$\begin{array}{c}\text { Cook yield } \\
(\%)\end{array}$} & \multirow{2}{*}{$\begin{array}{l}\text { Peroxide values } \\
\qquad(\mathrm{mg} / \mathrm{kg})\end{array}$} \\
\hline & $\mathrm{pH}$ & Temperature $\left({ }^{\circ} \mathrm{C}\right)$ & & & & \\
\hline $\mathrm{A}_{0}$ & 6.05 & $27.83^{q}$ & not measured & 0.68 & 46.82 & $3.891^{\mathrm{p}}$ \\
\hline $\mathrm{A}_{1}$ & 6.04 & $28.33^{\mathrm{q}}$ & 6.19 & 0.61 & 46.66 & $2.594^{\mathrm{rs}}$ \\
\hline $\mathrm{A}_{2}$ & 6.08 & $29.00^{\mathrm{p}}$ & 6.12 & 0.57 & 45.47 & $3.597^{\mathrm{pq}}$ \\
\hline $\mathrm{A}_{3}$ & 6.07 & $28.33^{q}$ & 6.27 & 0.60 & 46.81 & $2.928^{\mathrm{qr}}$ \\
\hline $\mathrm{A}_{4}$ & 6.03 & $29.00^{p}$ & 6.15 & 0.68 & 47.88 & $1.998^{\mathrm{s}}$ \\
\hline Standar error & 0.05 & 0.15 & 0.05 & 0.02 & 0.93 & 0.201 \\
\hline
\end{tabular}

${ }^{\mathrm{p}-\mathrm{s}}$ Means within same column with different superscripts are different $(\mathrm{P}<0.05)$

The Preincubated $\mathrm{pH}$ becomes the ideal conditions for the formation of nitric acid $\left(\mathrm{HNO}_{2}\right)$ as reported Honikel (2004); Pegg \& Shahidi (2000). Nitric acid is in equilibrium with $\mathrm{N}_{2} \mathrm{O}_{3}$, which dissociates to form nitric oxide (NO) and nitrogen dioxide $\left(\mathrm{NO}_{2}\right)$. The NO then can react with the myoglobin to produce dark red NO-myoglobin, then converted to pink stable nitrosylhemochrome upon heating (Sebranek 2009).

The temperature of the mixture was measured only when pre-incubate ranged from 27.83 to $29.00^{\circ} \mathrm{C}$. There were significant differences $(\mathrm{P}<0.05)$ of pre-incubate temperature of the mixture between treatments. The temperature of the mixture of $\mathrm{A}_{2}$ and $\mathrm{A}_{4}$ significantly higher $(\mathrm{P}<0.05)$ than the temperature of the mixture of $\mathrm{A}_{0}, \mathrm{~A}_{1}$ and $\mathrm{A}_{3}$. It can be presumed because $\mathrm{A}_{2}$ and $\mathrm{A}_{4}$ using fresh celery leaves more. Cook yield of all treatments ranged from $45.47 \%$ to $47.88 \%$ and no significant differences $(\mathrm{P}>0.05)$ were found between any treatments for product yields. It suggests that uniform drying took place. Finished product (oven dried dendeng sapi) water activities of the all treatments ranged between 0.57 and 0.68 that were expected to inhibit the growth of spoilage and pathogenic bacteria. Most spoilage bacteria will not grow under $\mathrm{a}_{\mathrm{w}}$ of 0.91 and pathogenic bacteria such as Staphylococcus aureus are limited by an $\mathrm{a}_{\mathrm{w}}$ of 0.86 (Jay et al. 2005). No significant differences $(\mathrm{P}>0.05)$ were found between treatments for water activity indicating that all batches of dendeng sapi were produced in a uniform condition.

\section{Color measurement}

CIE $a^{*}$ (redness) values of no-sodium nitrite dendeng sapi $\left(\mathrm{A}_{1}-\mathrm{A}_{4}\right)$ and sodium nitrite-added $\left(\mathrm{A}_{0}\right)$ indicated that the color was not red because all values were under zero. It was presumed pink cured color produced by the curing reaction covered by a brown color resulted from the browning reaction due to heating temperature of $63^{\circ} \mathrm{C}$ for 4 hours to the brown sugar and the white sugar added to the product which totals $33 \%$ of the meat used weight.

No significant interactions $(\mathrm{P}>0.05)$ were found between treatments and storage times for CIE $a^{*}$ values as reported in Table 2, but the main effect of storage times (time of observation) significantly different $(\mathrm{P}<0.05)$ as reported in Table 3. CIE $a^{*}$ values significant $(\mathrm{P}<0.05)$ increased throughout storage times toward the red color values (zero). The nitrate concentration in fresh celery leaves as a reservoir for curing reactions may 
explain this occurence. According to Keeton et al. (2009), the nitrate concentration of celery average of $1496 \mathrm{ppm}$ with the range of $20-4269 \mathrm{ppm}$ and the nitrite concentration of celery average of $0.1 \mathrm{ppm}$ with the range from 0.02 to $0.5 \mathrm{ppm}$. According to Sebranek (2009), nitrite is highly reactive as a curing agent so that it will run out relatively quick from cured meat. Nitrate serves as an important reservoir in cured meat products to maintain an effective concentration of nitrite during heating/drying or storage in the long term.

Table 2. The means for residual nitrite, cured pigment, total pigment and CIE $L^{*}, a^{*}, b^{*}$ values at various storage times

\begin{tabular}{|c|c|c|c|c|c|c|c|}
\hline \multirow{2}{*}{ Treatments } & \multicolumn{3}{|c|}{ Storage times } & \multirow{2}{*}{ Treatments } & \multicolumn{3}{|c|}{ Storage times } \\
\hline & 0 & 14 & 28 & & 0 & 14 & 28 \\
\hline \multicolumn{4}{|c|}{ Residual nitrite (ppm) } & \multicolumn{4}{|c|}{ CIE $L^{*}$ (lightness) values } \\
\hline $\mathrm{A}_{0}$ & 0.060 & 0,084 & 0.050 & $\mathrm{~A}_{0}$ & 46.762 & 41.666 & 41.992 \\
\hline $\mathrm{A}_{1}$ & 0.048 & 0.073 & 0.054 & $\mathrm{~A}_{1}$ & 40.807 & 41.851 & 42.477 \\
\hline $\mathrm{A}_{2}$ & 0.053 & 0.089 & 0.035 & $\mathrm{~A}_{2}$ & 44.196 & 43.349 & 44.303 \\
\hline $\mathrm{A}_{3}$ & 0.038 & 0.083 & 0.045 & $\mathrm{~A}_{3}$ & 42.080 & 40.496 & 41.978 \\
\hline $\mathrm{A}_{4}$ & 0.061 & 0.072 & 0.083 & $\mathrm{~A}_{4}$ & 40.140 & 40.655 & 38.148 \\
\hline SEM a & 0.006 & & & SEM $^{\text {a }}$ & 0.542 & & \\
\hline \multicolumn{4}{|c|}{ Cured pigment (nitrosylhemochrome) } & \multicolumn{4}{|c|}{ CIE $a^{*}$ (redness) values } \\
\hline $\mathrm{A}_{0}$ & 57.855 & 113.293 & 189.853 & $\mathrm{~A}_{0}$ & -3.177 & -2.505 & -2.603 \\
\hline $\mathrm{A}_{1}$ & 37.072 & 141.230 & 139.683 & $\mathrm{~A}_{1}$ & -5.093 & -5.605 & -4.197 \\
\hline $\mathrm{A}_{2}$ & 99.470 & 155.150 & 186.180 & $\mathrm{~A}_{2}$ & -6.066 & -5.139 & -4.971 \\
\hline $\mathrm{A}_{3}$ & 41.180 & 146.933 & 211.217 & $\mathrm{~A}_{3}$ & -5.912 & -4.540 & -4.207 \\
\hline $\mathrm{A}_{4}$ & 35.090 & 88.063 & 185.987 & $\mathrm{~A}_{4}$ & -5.931 & -5.504 & -4.929 \\
\hline $\mathrm{SEM}^{\mathrm{a}}$ & 13.353 & & & SEM $^{\text {a }}$ & 0.205 & & \\
\hline \multicolumn{4}{|c|}{ Total pigment } & \multicolumn{4}{|c|}{ CIE $b^{*}$ (yellowness) values } \\
\hline $\mathrm{A}_{0}$ & 444.040 & 260.893 & 244.120 & $\mathrm{~A}_{0}$ & 18.297 & 15.613 & 16.496 \\
\hline $\mathrm{A}_{1}$ & 577.433 & 248.653 & 424.547 & $\mathrm{~A}_{1}$ & 16.642 & 12.110 & 13.988 \\
\hline $\mathrm{A}_{2}$ & 340.567 & 384.427 & 493.227 & $\mathrm{~A}_{2}$ & 17.187 & 13.552 & 16.140 \\
\hline $\mathrm{A}_{3}$ & 371.280 & 264.293 & 338.867 & $\mathrm{~A}_{3}$ & 18.528 & 13.276 & 16.121 \\
\hline $\mathrm{A}_{4}$ & 247.633 & 259.080 & 471.240 & $\mathrm{~A}_{4}$ & 18.035 & 14,500 & 14.514 \\
\hline $\mathrm{SEM}^{\mathrm{a}}$ & 42.901 & & & SEM $^{\mathrm{a}}$ & 0.527 & & \\
\hline
\end{tabular}

a SEM: standard error of the means 
Table 3. The means for the main effect of storage times (days $0,14,28$ ) for CIE $a^{*}$ and $b^{*}$ values and cured pigment

\begin{tabular}{lcccc}
\hline \hline \multirow{2}{*}{ Research parameter } & \multicolumn{3}{c}{ Storage times } & \multirow{2}{*}{ Standard error } \\
\cline { 2 - 5 } & 0 & 14 & 28 & 0.205 \\
\hline CIE $a^{*}$ (redness) & $-5.236^{\mathrm{q}}$ & $-4.658^{\mathrm{pq}}$ & $-4.181^{\mathrm{p}}$ & 0.527 \\
CIE $b^{*}$ (yellowness) & $17.738^{\mathrm{p}}$ & $13.810^{\mathrm{q}}$ & $15.452^{\mathrm{pq}}$ & 13.353 \\
Cured pigment $(\mathrm{ppm})$ & $54.133^{\mathrm{q}}$ & $128.934^{\mathrm{pq}}$ & $182.584^{\mathrm{p}}$ & \\
\hline
\end{tabular}

${ }^{\mathrm{p}-\mathrm{q}}$ Means within same row with different superscripts are significant different $(\mathrm{P}<0.05)$

Table 4. The means for the main effect of curing treatment

\begin{tabular}{lcccccc}
\hline \hline \multirow{2}{*}{ Research parameter } & \multicolumn{5}{c}{ Treatments } & Standard \\
\cline { 2 - 6 } & $\mathrm{A}_{0}$ & $\mathrm{~A}_{1}$ & $\mathrm{~A}_{2}$ & $\mathrm{~A}_{3}$ & $\mathrm{~A}_{4}$ & error \\
\hline $\mathrm{a}^{*}$ (redness) & $-2.762 \mathrm{p}$ & $-4.965 \mathrm{q}$ & $-5.392 \mathrm{q}$ & $-4.886 \mathrm{q}$ & $-5.454 \mathrm{q}$ & 0.205 \\
\hline
\end{tabular}

p-q Means within same row with different superscripts are significant different $(\mathrm{P}<0.05)$

Table 5. The means for proximate composition of dendeng sapi

\begin{tabular}{lccc}
\hline \hline Treatments & Moisture & Fat & Protein \\
\hline & & $(\%)$ & \\
\cline { 2 - 4 } $\mathrm{A}_{0}$ & 19.92 & 5,20 & 29.22 \\
$\mathrm{~A}_{1 / 3}$ & 22.11 & 5.54 & 28.08 \\
$\mathrm{~A}_{2 / 4}$ & 20.66 & 4.75 & 28.37 \\
Standard error & 0.57 & 0.50 & 0.99 \\
\hline
\end{tabular}

The mean for CIE $L^{*}$ (lightness) values of dendeng sapi in various storage times (days 0,14 and 28) are reported in Table 2. No interaction was presented for treatment $\mathrm{x}$ storage times for CIE $L^{*}$ values of dendeng sapi. CIE $L^{*}$ values generally remained similiar throughout storage times which showed cured color not fading throughout storage times. Although no significant difference, $\mathrm{A}_{0}$ or the control revealed a lighter color than all other treatments at day 0. According to Sindelar et al. (2010) a lighter color suggests the presence of more darkish-colored metmyoglobin pigment and less reddish-colored nitrosylhemochrome pigment. According to Pegg \& Shahidi (2000), when nitrite is added to ground beef, browning effect occurs because nitrite is so a strong oxidant to the heme in myoglobin that myoglobin and oxymyoglobin were oxidised to metmyoglobin. Reduction of nitrite into nitric acid make an unstable intermediate pigment (nitrosylmetmyoglobin) formed. Presume due to absence of adequate endogenous and exogenous reductants, nitrosylmetmyoglobin pigments can not autoreduct to form more stable dark red NOmyoglobin or nitrosylmyoglobin.

The mean for CIE $L^{*}$ values of $\mathrm{A}_{0}$ or the control showed higher (not significant) at day 0 than at $14^{\text {th }}$ and $28^{\text {th }}$ storage day due to the decreasing of nitrosylhemochrome pigment or fading cured color throughout storage times. This can be explained that $\mathrm{A}_{0}$ is only added sodium nitrite and no nitrates added as a backup source of nitrite to the regeneration reaction curing color development and stability throughout the storage times. 
The mean for CIE $b^{*}$ (yellowness) values of dendeng sapi from all treatments at various storage times (days $0,14,28$ ) are reported in Table 2 . No interaction was present for treatment $\mathrm{x}$ storage times for CIE $b^{*}$ values but the main effect of storage times (time observation) was significantly different $(\mathrm{P}<0.05)$ as reported in Table 3 . CIE $b^{*}$ values were generally significantly decreased $(\mathrm{P}<0.05)$ at day14 of storage compared with day 0 of storage and significantly increased $(\mathrm{P}<0.05)$ or remained at day 28 compared with day 14 of storage. CIE $b^{*}$ values were generally significantly decreased $(\mathrm{P}<0.05)$ or remained at day 28 compared with day 0 of storage.

\section{Proximate composition}

Proximate composition was represented by the sample of conventional curing treatment $\mathrm{A}_{0}$ or the control with a curing agent in the form of sodium nitrite and the sample of natural curing treatment with a curing agent in the form of $22 \mathrm{~g}$ or $36 \mathrm{~g}$ of fresh celery leaves which were randomly selected among incubated at room temperature or at a temperature of $40.6^{\circ} \mathrm{C}$. Proximate composition is presented in Table 5. The proximate composition of oven dried/raw dendeng sapi all treatments for moisture ranged from 19.92 to $22.11 \%$; for fat ranged from 4.75 to $5.54 \%$ and for protein ranged from 28.08 to $29.22 \%$. No significant difference $(\mathrm{P}>0.05)$ were found for proximate composition between all treatments. It showed that concentration of fresh celery leaves added did not affect proximate composition and all treatments were uniformly in the proximate composition.

\section{Peroxide values}

A significant difference $(\mathrm{P}<0.05)$ was observed for lipid oxidation measured by peroxide value at day 28 of storage as reported in Table 1 . The mean for peroxide values ranged between 1.998 and $3.891 \mathrm{mg}$ equivalent of $\mathrm{O}_{2} / \mathrm{kg}$. Peroxide values were significant $(\mathrm{P}<0.05)$ the lowest in the $\mathrm{A}_{4}$ and significan $(\mathrm{P}<0.05)$ the highest in the $\mathrm{A}_{0}$. It suggests that the $22 \mathrm{~g}$ or $36 \mathrm{~g}$ of fresh celery leaves used as an agent of natural curing was more effective as an antioxidant of lipid oxidation suppressing during storage times compared with an agents of conventional curing in the form of synthetic sodium nitrite $(50 \mathrm{ppm})$. A natural curing by incubation at room temperature for 2 hours with $22 \mathrm{~g}$ of fresh celery leaves significantly produces lower peroxide values $(\mathrm{P}<0.05)$ than with $36 \mathrm{~g}$ of fresh celery leaves. It suggests that the natural curing by incubation at room temperature for 2 hours with $22 \mathrm{~g}$ of fresh celery leaves was more effective as an antioxidant of fat oxidation suppressing during storage times. Instead of a natural curing by incubation at a temperature of $40.6^{\circ} \mathrm{C}$ for 2 hours with $36 \mathrm{~g}$ of fresh celery leaves significantly produces lower peroxide values $(\mathrm{P}<0.05)$ than with $22 \mathrm{~g}$ of fresh celery leaves. It showed that $36 \mathrm{~g}$ of fresh celery leaves used as an agent of natural curing will be more effective as an antioxidant of lipid oxidation suppressing during storage times if it was incubated at a temperature of $40.6^{\circ} \mathrm{C}$.

\section{Cured pigment and total pigment}

No significant differences $(\mathrm{P}>0.05)$ were observed for the treatment $\mathrm{x}$ storage times interaction for cured pigment concentration of each treatment at various periods of storage but the main effect of storage times was different significantly $(\mathrm{P}<0.05)$ as presented in Table 3. Trends indicated that cured pigment concentration generally increased significantly $(\mathrm{P}<0.05)$ over time of storage regardless of treatment of fresh celery leaves 
concentration and applied incubation temperature. It showed that the level of formulated fresh celery leaves and applied incubation temperature did not appear to be as important as the amount of time required for enzyme of nitrate reductase of fresh celery leaves or fresh beef to convert nitrate to nitrite and then into nitric oxide (NO) to result in cured pigment development. Lee \& Cassens (1976) concluded that a minimum of two hours of incubation is required to convert $90 \%$ of nitrite to nitric oxide (NO) and bound with myoglobin to nitrosylmyoglobin formation. According to Cassens et al. (1979) and Shahidi \& Pegg (1992), after heating, the globin portion of nitrosylmyoglobin were denatured and escaped from the iron atom to form stable nitrosylmyochrome or nitrosylhemochrome.

Although it was not significantly different, trends at any time observations showed that incubation temperature of $40.6^{\circ} \mathrm{C}$ in natural curing with $22 \mathrm{~g}$ of fresh celery leaves was capable of producing nitric oxide (NO) for cured pigment formation more resulting from conversion of nitrate of fresh celery leaves to nitrite compared with incubation at room temperature. It did not occur in natural curing with $36 \mathrm{~g}$ of fresh celery leaves, opposite happened where incubation temperature of $40.6^{\circ} \mathrm{C}$ produce less of nitric oxyde compared with incubation at room temperature.

Means for total pigment concentration of treatments over storage times are reported in Table 2. No significant differences $(\mathrm{P}>0.05)$ for treatment $\mathrm{x}$ storage times interaction were observed for total pigment concentration of each treatment at various storage times. It suggested that bottom round differences from different local beef cattle carcasses utilized randomly for dendeng sapi mixture of each treatment did not cause variation in total pigments. Although no significant differences, total pigment analysis revealed that total pigment concentration for $\mathrm{A}_{0}$ decreased over storage times. This may be explained because of depleting amounts of nitrite reservoir in $\mathrm{A}_{0}$ over storage times. Total pigment for $\mathrm{A}_{2}$ and $\mathrm{A}_{4}$ showed an increasing trend over storage times although no significant difference. Total pigment for $A_{1}$ and $A_{3}$ showed a decreasing trend at day 14 and then increased at day 28 of storage although no significant difference.

\section{Residual nitrite}

Residual nitrite at pre- and post-incubation of all treatments was very slightly under $0.1 \mathrm{ppm}$ or nearly undetectable. It suggested that nitrite available had been exhausted in the quick curing reactions during chopping and mixing dendeng sapi mixture. No significant differences $(\mathrm{P}>0.05)$ were found for residual nitrite at pre- or post-incubate in any treatments (Table 6). Residual nitrite at post-incubate of all treatments is not significant compared with pre-incubate. It showed the importance of the incubation time required for the conversion of nitrate to nitrite. According Sindelar et al. (2007a) as incubation time increased, level of nitrite was also increased.

All treatments contain residual nitrite very slightly under $0.1 \mathrm{ppm}$ or nearly undetectable during the storage times as at pre- and post-incubation of dendeng sapi mixtures. This suggested that available nitrite were used in the regeneration of the rapid curing reactions during the storage times. No significant interaction $(\mathrm{P}>0.05)$ of treatment $\mathrm{x}$ storage times for residual nitrite between all treatments (Table 2). The residual nitrite of all treatments increased at day 14 of storage and then decreased at day 28 of storage (not significant). A decreasing in the residual nitrite although it was not significantly different at day 28 of storage was as expected, the levels of residual nitrite diminished over time for all treatments. This observation has been well documented by Jantawat et al. (1993), who found a decreasing residual nitrite level with increasing storage times relationship, and by Hustad et al. (1973), who reported that nitrite concentration was affected by storage times and storage temperature. Another explanation was suggested by Ahn et al. (2002), who 
noted packaging effect in sausage samples stored in vacuum packages compared with aerobic packages. These authors reported that vacuum-packaged sausages had lower residual nitrite than samples stored in aerobic conditions. The authors suggested that this phenomenon was caused by the product environment being in the reduced state thus allowing the conversion of nitrite to nitric oxide and resulting in the lower residual nitrite levels found.

Table 6. Means for residual nitrite at pre and post-incubate

\begin{tabular}{lcc}
\hline \hline \multirow{2}{*}{ Treatments } & \multicolumn{2}{c}{ Residual nitrite $(\mathrm{ppm})$} \\
\cline { 2 - 3 } & Pre-incubate & Post-incubate \\
\hline $\mathrm{A}_{0}$ & 0.075 & not measured \\
$\mathrm{A}_{1}$ & 0.053 & 0.046 \\
$\mathrm{~A}_{2}$ & 0.048 & 0.061 \\
$\mathrm{~A}_{3}$ & 0.062 & 0.073 \\
$\mathrm{~A}_{4}$ & 0.042 & 0.043 \\
Standard error & 0.006 & 0.010 \\
\hline
\end{tabular}

Each pair of treatment combinations $\left(\mathrm{A}_{1}\right.$ and $\mathrm{A}_{3} ; \mathrm{A}_{2}$ and $\left.\mathrm{A}_{4}\right)$ where celery leaves level held was constant, residual nitrite levels were not significantly different $(\mathrm{P}>0.05)$ when the incubation temperatures increased or were differentiated between room temperature and temperature of $40.6^{\circ} \mathrm{C}$ (Table 3). This pattern occured at all days over the 28 - $\mathrm{d}$ storage times. It showed that the celery leaves levels of $22 \mathrm{~g}$ or $36 \mathrm{~g}$ produced the same levels of residual nitrite converted from nitrates during the 120 minutes of incubation at room temperature or at temperature of $40.6^{\circ} \mathrm{C}$ compared with $\mathrm{A}_{0}$ or the control of sodium nitriteadded $(50 \mathrm{ppm})$. Available nitrite were reacted through curing reactions result in low amount of nitrite of all treatments and over storage times.

The residual nitrite of oven dried dendeng sapi of all treatments at days 0,14 and 28 storage still showed safe limits for consumption related methaemoglobinemia and or the formation of carcinogenic nitrosamines in the human body. BPOM RI has set the daily consumption which does not pose a danger to health (Acceptable daily intake, ADI) for potassium or sodium nitrite by 0 to $0.06 \mathrm{ppm}$ or $\mathrm{mg} / \mathrm{kg}$ body weight (BPOM 2013). The lethal doses of sodium nitrite for humans has been reported to be approximately $1 \mathrm{~g}$ (Ellenhorn \& Barceloux 1988).

\section{Sensory quality}

The means score for all sensory quality attributes are presented in Table 7. All sensory quality attributes (cured aroma, celery aroma, cured color, color uniformity, firmness and celery flavor among all treatments were different $(\mathrm{P}<0.05)$ except for the cured flavor $(\mathrm{P}>0.05)$. No different cured flavor guessed because the enzyme of nitrate reductase from $22 \mathrm{~g}$ and $36 \mathrm{~g}$ of fresh celery leaves incubated for 2 hours either at room temperature or at temperature of $40.6^{\circ} \mathrm{C}$ used in this study has reckoned capable of producing the equivalent of $30 \mathrm{ppm}$ and $50 \mathrm{ppm}$ nitrite $(\mathrm{n}=3)$. MacDonald et al. (1980) found that nitrite levels of $50 \mathrm{ppm}$ were sufficient to induce cured flavor as identified by the consumer sensory test.

$\mathrm{A}_{1}$ had no significant differences $(\mathrm{P}>0.05)$ for sensory quality attributes of cured color, firmness and cured flavor the same curing but significantly different $(\mathrm{P}<0.05)$ for cured aroma and color uniformity compared with $\mathrm{A}_{0} . \mathrm{A}_{2}$ had significant differences 
$(\mathrm{P}<0.05)$ for all sensory quality attributes compared with $\mathrm{A}_{0} . \mathrm{A}_{3}$ had no significant differences $(\mathrm{P}>0.05)$ for all sensory quality attributes compared with $\mathrm{A}_{0}$. $\mathrm{A}_{4}$ had no significant differences $(\mathrm{P}>0.05)$ for sensory quality attributes of color uniformity and cured flavor but significantly different $(\mathrm{P}<0.05)$ for cured aroma, cured color and firmness compared with $\mathrm{A}_{0}$.

Table 7. Means for sensory quality attributes

\begin{tabular}{lccccccc}
\hline \hline Treatments & $\begin{array}{c}\text { Cured } \\
\text { aroma }\end{array}$ & $\begin{array}{c}\text { Cured } \\
\text { flavor }\end{array}$ & $\begin{array}{c}\text { Cured } \\
\text { color }\end{array}$ & $\begin{array}{c}\text { Color } \\
\text { uniformity }\end{array}$ & Firmness & $\begin{array}{c}\text { Celery } \\
\text { aroma }\end{array}$ & $\begin{array}{c}\text { Celery } \\
\text { flavor }\end{array}$ \\
\hline $\mathrm{A}_{0}$ & $10.76^{\mathrm{a}}$ & 10.61 & $8.91^{\mathrm{a}}$ & $10.96^{\mathrm{a}}$ & $5.48^{\mathrm{e}}$ & - & - \\
$\mathrm{A}_{1}$ & $8.67^{\mathrm{d}}$ & 10.03 & $7,77^{\mathrm{c}}$ & $8.75^{\mathrm{d}}$ & $6.15^{\mathrm{d}}$ & $1.60^{\mathrm{d}}$ & $3.10^{\mathrm{c}}$ \\
$\mathrm{A}_{2}$ & $8.12^{\mathrm{e}}$ & 8.47 & $6.70^{\mathrm{d}}$ & $8.58^{\mathrm{e}}$ & $6.81^{\mathrm{b}}$ & $3.64^{\mathrm{b}}$ & $4.15^{\mathrm{a}}$ \\
$\mathrm{A}_{3}$ & $9.34^{\mathrm{b}}$ & 9.49 & $8.21^{\mathrm{b}}$ & $10,11^{\mathrm{c}}$ & $6.81^{\mathrm{c}}$ & $1.72^{\mathrm{c}}$ & $2.54^{\mathrm{d}}$ \\
$\mathrm{A}_{4}$ & $8.84^{\mathrm{c}}$ & 9.19 & $5.72^{\mathrm{e}}$ & $10.50^{\mathrm{b}}$ & $7.99^{\mathrm{a}}$ & $3.19^{\mathrm{a}}$ & $3.48^{\mathrm{b}}$ \\
$\mathrm{SEM}^{\mathrm{f}}$ & 0.30 & 0.29 & 0.26 & 0.24 & 0.25 & 0.24 & 0.25 \\
\hline
\end{tabular}

a-e Means on the same column with different superscripts are significant different $(\mathrm{P}<0.05)$

${ }^{\mathrm{f}} \mathrm{SEM}$ : standard error of the means

$\mathrm{A}_{0}$ or the control received the highest score for all sensory attributes except firmness. $A_{0}$ had a significantly $(P<0.05)$ higher score for cured aroma than $A_{1}, A_{2}, A_{3}$ and $A_{4}$. No differences $(\mathrm{P}>0.05)$ were found between all treatments for cured flavor but $\mathrm{A}_{0}$ or the control had a significantly $(\mathrm{P}<0.05)$ higher score for cured flavor than $\mathrm{A}_{1}, \mathrm{~A}_{2}, \mathrm{~A}_{3}$ and $\mathrm{A}_{4}$. $A_{0}$ had a significantly $(P<0.05)$ higher score for cured color and color uniformity than $A_{1}$, $\mathrm{A}_{2}, \mathrm{~A}_{3}$ and $\mathrm{A}_{4}$. $\mathrm{A}_{4}$ had a significantly $(\mathrm{P}<0.05)$ lower score for cured color than $\mathrm{A}_{0}, \mathrm{~A}_{1}, \mathrm{~A}_{2}$, and $A_{3} . A_{2}$ had a significantly $(P<0.05)$ lower score for color uniformity than $A_{0}, A_{1}, A_{3}$ and $\mathrm{A}_{4}$. $\mathrm{A}_{0}$ had a significantly $(\mathrm{P}<0.05)$ lower score for firmness than $\mathrm{A}_{1}, \mathrm{~A}_{2}, \mathrm{~A}_{3}$ and $\mathrm{A}_{4}$. It did not agree with Pegg \& Shahidi (2000) reported that the curing reactions of nitrite increase firmness.

Trained sensory analysis showed the aroma and flavor of celery which tend to approach did not exist in the product. This may have been due to the dendeng sapi spices used, which could provide a predominant aroma and flavor and result in aroma and flavor of celery masking in dendeng sapi.

\section{CONCLUSION}

The natural curing treatment by fresh celery leaves in this study was comparable to the conventional curing treatment by sodium nitrite-added $(50 \mathrm{ppm})$. Sensory analysis showed celery aroma and celery flavor scores tend to approach undetectable as a result of the masking by spices used. The results indicated that the natural curing treatment by $22 \mathrm{~g}$ of fresh celery leaves and incubated at room temperature was the best of natural curing formulation.

\section{ACKNOWLEDGEMENT}

This research was funded by Tugas Belajar Programme of Indonesian Agency for Extension and Human Resource Development of Agriculture, Ministry of Agriculture Republic of Indonesia 2014-2016. 


\section{REFERENCES}

Ahn HJ, Kim JH, Jo C, Lee CH, Byun MW. 2002. Reduction of carcinogenic nnitrosamines and residual nitrite in model system sausage by irradiation. J Food Sci. 67:1370-1373.

AOAC. 1990a. Fat (crude) or ether extract in meat (AOAC 960.39). In: Official Methods of Analysis. 15th Ed. Arlington (USA): Association of Official Analytical Chemists Inc. p. 2:931-948.

AOAC. 1990b. Moisture in meat (AOAC 950.46). In: Official Methods of Analysis. 15th Ed. Arlington (USA): Association of Official Analytical Chemists Inc. p. 2:931-948.

AOAC. 1990c. Nitrite in cured meat. In: Official Methods of Analysis. 15th Ed. Arlington (USA): Association of Official Analytical Chemists Inc. p. 973.31.

AOAC. 1993. Crude protein in meat and meat products (AOAC 992.15). In: Official Methods of Analysis. 15th Ed., 4th suppl. Arlington (USA): Association of Official Analytical Chemists Inc. p. 197-198.

AOAC. 1997. Offical Method of Peroxide Value of Oils and Fats. The Association of Analytical Chemists Inc. Arlington (USA): Association of Official Analytical Chemists Inc.

BPOM. 2013. Peraturan Kepala BPOM RI Nomor 36 Tahun 2013 tentang Batas Maksimum Penggunaan Bahan Tambahan Pangan Pengawet. Jakarta (Indonesia): Badan Pengawas Obat dan Makanan.

Cassens RG, Greaser ML, Lee M. 1979. Reactions of nitrite in meat. Food Tech. 33:46-57.

Ellenhorn MJ, Barceloux DG. 1988. Medical toxicology. New York (USA): Elsevier.

Fujihara SA, Kasuga, Aoyagi Y. 2001. Nitrogen-to-protein conversion factors for common vegetables in Japan. J Food Sci. 66:412-415.

Honikel KO. 2004. Curing agents. In: Jensen WK, Devine C, Dikeman M, editors. Encyclopedia of meat sciences. Oxford (UK): Elsevier. p. 195-201.

Hustad GO, Cerveny JH, Trenk H, Deibel RH, Kautter DA, Fazio T, Johnston RW, Kolari OE. 1973. Effect of sodium nitrite and sodium nitrate on botulinal toxin production and nitrosamine formation in wieners. Appl Microbiol. 26:22-6.

Jantawat P, Runglerdkriangkrai J, Thunpithayakul C, Sanguandeekul R. 1993. Effects of initial nitrite level on residual nitrite and spoilage of canned ham roll. J Food Qual. 16:1-11.

Jay JM, Loessner MJ, Golden DA. 2005. Modern food microbiology (7th ed.). New York (USA): Springer.

Keeton JT, Osburn WN, Hardin MD, Bryan NS, Longnecker MT. 2009. A national survey of the nitrite/nitrate concentrations in cured meat products and nonmeat foods available at retail, American meat institute foundation report [Internet]. [cited August 11, 2015]. Available from: http://www.amif.org/ht/a/GetDocument Action/1/52741.

Lee SH, Cassens RG. 1976. Nitrite binding sites on myoglobin. J Food Sci. 41:969-970.

MacDonald B, Gray JI, Stanley DW, Usborne WR. 1980. Role of nitrite in cured meat favor: Sensory analysis. J Food Sci. 45:885-904.

McDougall DB, Mottram DS, Rhodes DN. 1975. Contribution of nitrite and nitrate to the colour and flavour of cured meats. J Sci Food Agric. 26:1743-1754.

Pegg RB, Shahidi F. 2000. Nitrite curing of meat. Trumbull (USA): Food \& Nutrition Press Inc. p. 7-66.

Pinotti A, Graiver N, Califano A, Zaritzky N. 2001. Diffusion of nitrite and nitrate salts in pork tissue in the presence of natrium chloride. J Food Sci. 67:2165-2171. 
Sanz Y, Vila R, Toldrá F, Nieto P, Flores J. 1997. Effect of nitrate and nitrite curing salts on microbial changes and sensory quality of rapid ripened sausages. Int $\mathrm{J}$ Food Microbiol. 37:225-229.

Sebranek JG, Bacus JN. 2007. Natural and organic cured meat products: Regulatory, manufacturing, marketing, quality and safety issues (American Meat Science Association White Paper Series No. 1) [Internet]. [cited August 11, 2015]. Available from: American Meat Science Association Web site: http//www.meatscience.org/Pubs/White\%20Papers/ wp_001_2007_Natural_Organic_Cured_Meat.pdf.

Sebranek JG. 1979. Advances in the technology of nitrite use and consideration of alternatives. Food Tech. 33:58-62.

Sebranek JG. 2009. Basic curing ingredients. In: Tarte R, editor. Ingredients in Meat Products. New York (USA): Springer Science+Business Media LLC.

Sebranek JG, Lonergan SM, King-Brink M, Larson E. 2001. Meat science and processing. 3rd Ed. Virginia (USA): Peerage Press. p. 141.

Shahidi F, Pegg RB. 1992. Nitrite-free meat curing systems: update and review. Food Chem. 43:185-191.

Shahidi F and Pegg RB. 1994. Absence of volatile N-nitrosamines in cooked nitrite-free cured muscle foods. Meat Sci. 37:327-336.

Sindelar JJ, Cordray JC, Sebranek JG, Love JA, Ahn DU. 2007a. Effects of vegetable juice powder concentration and storage times on some chemical and sensory quality attributes of uncured, emulsified cooked sausages. J Food Sci. 72:S324-S332.

Sindelar JJ, Cordray JC, Sebranek JG, Love JA, Ahn DU. 2007b. Effects of varying levels of vegetable juice powder and incubation time on color, residual nitrate and nitrite, pigment, $\mathrm{pH}$, and trained sensory attributes of ready-to-eat uncured ham. J Food Sci. 72:S388-S395.

Sindelar JJ, Terns MJ, Meyn E, Boles JA. 2010. Development of a method to manufacture uncured, no-nitrate/nitrite-added whole muscle jerky. Meat Sci. 86:298-303.

Suryati T, Astawan M, Lioe HN, Wresdiyati T, Usmiati S. 2014. Nitrite residue and malonaldehyde reduction in dendeng-Indonesian dried meat-influenced by spices, curing methods and precooking preparation. Meat Sci. 96:1403-1408.

Terns MJ, Milkowski AL, Claus JR, Sindelar JJ. 2011a. Investigating the effect of incubation time and starter culture addition level on quality attributes of indirectly cured, emulsified cooked sausages. Meat Sci. 88:454-461.

Terns MJ, Milkowski AL, Rankin SA, Sindelar JJ. 2011b. Determining the impact of varying levels of cherry powder and starter culture on quality and sensory attributes of indirectly cured, emulsified cooked sausages. Meat Sci. 88:311-318.

Walker R. 1990. Nitrates, nitrite and N-nitrosocompounds: a review of the occurrence in food and diet and the toxicological implications. Food Addit Contam. 7:717-768. 